\title{
Technological Resources Used in Virtual Learning and Coping Strategies of Nursing Students
}

\author{
Reymarc P. Galiendo ${ }^{1}$, Christopher Lee R. Castro ${ }^{2}$, Revecca B. Comillas ${ }^{3}$, Daniella Kate A. Delos \\ Santos $^{4}$, Jimboy D.C De Luna ${ }^{5}$, Princess Mae C. Manangan ${ }^{6}$, Cheena Mallari ${ }^{7}$, Zuzette Catabona ${ }^{8}$ \\ $1,2,3,4,5,6,7,8$ Nueva Ecija University of Science and Technology
}

ARTICLE INFO
Article history:
DOI:
10.30595/pshms.v2i.220
Submitted:
December 6, 2021
Accepted:
January 21, 2022
Published:
January 26, 2022

\section{Keywords:}

Education, Technological Resources, Coping Strategies, Flexible Learning, Nursing Students

\begin{abstract}
The COVID-19 pandemic in the Philippines caused schools to shift from face-to-face learning to a flexible learning approach that partly requires technology to deal with. Given this solution, the implementation caused struggles for nursing students with limited technological resources. Thus, the researchers deemed it necessary to conduct this research to describe the technological resources used by the nursing students and the coping strategies they develop to manage their situation. This research used a quantitative descriptive-correlational approach; a total enumeration as sampling design gathered through questionnaire was utilized. Analysis of data revealed that most of the profile of respondents were female, from the rural area, monthly family income belonged to the low-income group (but not poor), the monthly budget for internet Php 1,001 to Php 1,500, and using a router. The result also showed that students get stressed out when they get disconnected in the online discussion. They also felt pressure in their academic subjects, resulting in ineffective learning and trouble uploading videos. Given these, the student's coping strategy is to download the PPT/PDF of the online lessons to manage the situation. Correlation analysis was used and revealed that all variables were correlated to each other. This study came up with a proposed program to augment limited technological resources with the aid of the school and in collaboration with other agencies that can address this concern.
\end{abstract}

This work is licensed under a Creative Commons Attribution 4.0 International License.

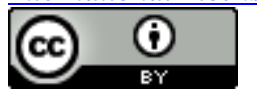

\section{Corresponding Author:}

Reymarc P. Galiendo,

Nueva Ecija University of Science and Technology, Gen. Tinio Street,

Cabanatuan City, Philippines, 3100

Email: galiendoreymarc@gmail.com

\section{INTRODUCTION}

Technology resources are information, tools, or devices that motivate students and give information or assistance with questions. Given the technological advancement nowadays, students are expected to develop technological fluency. Students come from school and home backgrounds where technology is not widely accessible or used, they will be at a disadvantage for technology-based tasks and miss out on tremendous educational opportunities with technology resources [1].Nevertheless, learning should not be halted. Several nations throughout the world used various methods to continue the schooling process during the pandemic where the shift of traditional face-to-face to flexible learning approach is the key to continue education, that is through the aid of technology. Google, TV broadcasts, instructions, resources, video lectures, and internet channels were offered as online learning platforms [2]

Technology has recently seen a pervasive integration into daily life, with easy access to large volumes of information. Today's students learn in a different way than previous generations. Technology is all around them, and they have instant access to a variety of knowledge. Ehrlich, Sporte, Sebring, and the Consortium on Chicago Schools (2013) discovered that while 92\% of pupils had access to technology at 
home, fewer than half used it for schoolwork. The poll of 219 teachers by the National Literacy Trust and financed by Crick Software revealed that 87 percent of instructors feel technology can engage kids with reading, writing, speaking, and listening, notably in terms of motivation, enjoyment, and confidence. However, the fact is that wifi is the most significant impediment to using technology to promote learning in the classroom. Indeed, less than half of students (48.4\%) have access to an iPad or laptop, and only two out of five $(39.3 \%)$ have access to a desktop computer. Access to newer technology is even scarcer, with only $2.3 \%$ of schools able to give access to Virtual Reality headsets, $1.4 \%$ to smart speakers, and $0.9 \%$ to wireless headphones. [3]

Various learning sectors in the Philippines have proposed numerous innovative programs, including new normal would-be in the classrooms in higher education institutions. Commission on Higher Education stated, that online learning tools such as zoom, Youtube, Edmodo, Google Classroom, Facebook, and Messenger should be improved [4]. However, the implementation would cause issues for students who have a restricted internet connection, no devices, and are poor, the Philippines has the slowest internet access in Asia [4]

Given the foreseeable risks, it is valuable to conduct this study that aimed to describe the technological resources used in virtual learning of the nursing students. Moreover, the coping strategies of the students' nurses were also described. The researchers deemed it necessary to conduct this research to provide a clear and actual picture of the current situations of nursing students who were subjected to flexible learning because of pandemic.

\section{RESEARCH METHOD}

This research used a quantitative descriptive-correlational approach and was conducted at Nueva Ecija University of Science and Technology, College of Nursing, during the months of January to May 2021. A total enumeration sampling technique was used gathering 502 nursing students across all level voluntarily participated in the study. The data collection instrument employed in this study was a 5-point Likert-type survey questionnaire consisted of four parts, in which part I contains the profile characteristics of the respondents that include year level, type of residence, monthly income, the monthly budget for internet/cell phone, and the type of internet connection used in virtual learning; part II which describe the technological resources used by the respondents specifically in terms of availability of internet connection and availability of computers/gadgets; part II statements regarding the virtual learning experiences of the respondents, particularly along with the following: submission of academic requirements, accomplishing laboratory skills requirements, and performing alternative delivery of learning (ADL) requirements and the part IV which is the coping strategies used by nursing students in their virtual class.

To describe the profile characteristics of the respondents which are the year level, type of residence, monthly family income, monthly budget for internet/cellphone and type of internet connection, frequency and percentage distribution was used. To describe the profile characteristics, the researcher was utilized this to measure the given proportion of a part to a whole of the respondents. To describe the technological resources, virtual learning experiences and coping strategies of the respondents, weighted mean and verbal descriptions was used. And Pearson R to see the correlation between the variables.

After the data gathering period was completed, the data were subjected to statistical treatment tabulated by the university statistician for proper presentation, analysis, interpretation, and discussion.

Upon approval of the survey questionnaire, the researchers secured the letter of approval from the Dean of the College of Nursing of NEUST. Respondents and procedures were subjected to stringent ethical scrutiny. The respondents supplied their responses voluntarily, and all data acquired for the study was kept totally private and confidential.

\section{RESULTS AND DISCUSSIONS}

Table 1. Profile Characteristics of the Respondents $(n=502)$

\begin{tabular}{lcc}
\hline \multicolumn{1}{c}{ Variables } & Frequency & Percentage \\
\hline Year Level & & \\
First year & 144 & 28.7 \\
Second year & 239 & 47.6 \\
Third year & 104 & 20.7 \\
Fourth year & 15 & 3.0
\end{tabular}

Type of Residence 


\begin{tabular}{lll} 
Rural & 379 & 75.5 \\
Urban & 123 & 24.5 \\
\hline
\end{tabular}

\section{Estimated Monthly Family}

Income

Below Php10,957 144

Php10,958 to Php 21,914 $233 \quad 46.41$

Php 21,915 to Php 43,828 $\quad 85 \quad 16.93$

Php 43,829 to Php 76,669 $\quad 23 \quad 4.58$

Php 76,670 to Php 131,484 $\quad 13 \quad 2.59$

Php 131,485 to Php 219,140 $\quad 4 \quad 0.85$

Php 219,141 and above $\quad 0 \quad 0$

Estimated Monthly Budget for

Internet/Cellphone Load

Php 500 and below 140

Php 501 to Php 1,000 113

113

Php 1,001 to Php 1,500 $\quad 146 \quad 29.1$

$\begin{array}{lll}\text { Php } 1,501 \text { and above } & 103 & 20.5\end{array}$

Type of Internet Connection

$\begin{array}{lll}\text { Mobile data } & 143 & 28.5\end{array}$

$\begin{array}{llr}\text { Pocket WIFI } & 41 & 8.2\end{array}$

$\begin{array}{lcc}\text { Router } & 318 & 63.35\end{array}$

Others, specify: $\quad 0 \quad 0$

Based on Table 1, most of the respondents are second-year and the majority are from rural areas. Based on the gathered data, most of the respondents belonged to a low-income group (but not poor). It also found that the majority of respondents spent Php 1,001 to Php 1,500 per month on virtual learning. In terms of internet type, the majority used a router connection.

Table 2. Technological Resources Used in Virtual Learning and Virtual Experiences

\begin{tabular}{|c|c|c|}
\hline Availability of Internet Connection & $\begin{array}{l}\text { Weighted } \\
\text { Mean }\end{array}$ & $\begin{array}{c}\text { Verbal } \\
\text { Interpretation }\end{array}$ \\
\hline $\begin{array}{l}\text { The internet connection in my place is too slow; the speed usually is } \\
\text { less than } 25 \mathrm{mpbs} \text {. }\end{array}$ & 3.58 & Agree \\
\hline $\begin{array}{l}\text { There is no internet connection in our area, I need to travel to the } \\
\text { nearby town to attend my online class. }\end{array}$ & 1.96 & Disagree \\
\hline \multicolumn{3}{|l|}{ Availability of Computer/Gadgets } \\
\hline $\begin{array}{l}\text { There is only one (1) computer at home, which I share with my } \\
\text { other siblings who are also attending their online class every day. }\end{array}$ & 2.94 & $\begin{array}{l}\text { Moderately } \\
\text { Agree }\end{array}$ \\
\hline $\begin{array}{l}\text { There is no readily available computer or gadget that I can use in my } \\
\text { virtual class. }\end{array}$ & 2.09 & Disagree \\
\hline \multicolumn{3}{|l|}{ Submission of Academic requirements } \\
\hline $\begin{array}{l}\text { I feel a lot of submission pressures in my academic subjects which } \\
\text { resulted to ineffective learning for me. }\end{array}$ & 3.57 & Agree \\
\hline $\begin{array}{l}\text { I cannot usually comply with the submission of my online } \\
\text { requirements on time because I missed a lot of my online class } \\
\text { through Google Meet or Zoom. }\end{array}$ & 2.24 & Disagree \\
\hline \multicolumn{3}{|l|}{ Accomplishing Laboratory Requirements } \\
\hline I experienced troubles in uploading my videos in skills laboratory. & 3.77 & Agree \\
\hline $\begin{array}{l}\text { I am not able to perform my return demonstration in my skills } \\
\text { laboratory. }\end{array}$ & 2.35 & Disagree \\
\hline \multicolumn{3}{|l|}{$\begin{array}{l}\text { Performing Alternative Delivery of Learning (ADL) } \\
\text { Requirements }\end{array}$} \\
\hline $\begin{array}{l}\text { I got stressed out when I got disconnected in my Google Meet RLE } \\
\text { duty. }\end{array}$ & 3.93 & Agree \\
\hline
\end{tabular}


Based on Table 2, in terms of the availability of an internet connection. It reveals that the highest mean was the statement "The internet connection in my place is too slow; the speed usually is less than $25 \mathrm{mpbs} "$. This means that the majority of students regard the inconsistent internet speed in their location as the most significant problem in the conduct of a virtual class.

Moreover, in terms of the availability of computers/gadgets of nursing students. It is shown from the table that the highest mean was the statement "There is only one (1) computer at home, which I share with my other siblings who are also attending their online class every day" with a weighted mean of 2.94 and a verbal interpretation of Moderately Agree. This means that the majority of students will be unable to purchase or provide additional learning materials for their virtual class.

Furthermore, in Submission of Academic Requirements, it was found that the assertion that the highest mean of 3.57 was for the statement that "I feel a lot of submission pressures in my academic subjects, which results in ineffective learning for me". This means that most of the students are struggling with the deadlines of their tasks when it comes to submission, thus compromising their learning in their virtual class.

Moreover, in accomplishing laboratory skills requirements. It can be seen from the data that the highest mean was the statement "I experienced troubles in uploading my videos in the skills laboratory", having a weighted mean of 3.77 and a verbal interpretation of " agree". This indicates that the majority of students are struggling to comply with video requirements in their skills laboratory.

And lastly, in terms of performing alternative delivery of learning (ADL) requirements. The highest mean of 3.93 was for the statement "I got stressed out when I got disconnected from my Google Meet ADL duty. This indicates that the majority of respondents are experiencing lower levels of happiness, which causes them to do poorly in school.

Table 3. Coping Strategies of the Students

\begin{tabular}{lcc}
\hline \multicolumn{1}{c}{ Coping Strategies } & $\begin{array}{c}\text { Weighted } \\
\text { Mean }\end{array}$ & $\begin{array}{c}\text { Verbal } \\
\text { Interpretation }\end{array}$ \\
\hline $\begin{array}{l}\text { I always download the PPT/PDF of our online lessons } \\
\text { because of the insufficient time to learn during my } \\
\text { online class. }\end{array}$ & 4.11 & Agree \\
$\begin{array}{l}\text { I am a frequent customer of computer and internet } \\
\text { shops in my area, because I spend my time here to } \\
\text { attend my online class. }\end{array}$ & 1.93 & Disagree \\
\hline
\end{tabular}

As can be shown from table 3, the statement "I always download the PPT/PDF of our online lessons because of the insufficient time to learn during my online class" garnered a weighted mean of 4.11 and a verbal interpretation of Agree. It implies that the majority of the respondents relied on the uploaded learning materials on the internet as their way of keeping up with the discussion and learning.

Table 4. Correlation between Profile of the Respondents and Technological Resources and Virtual Learning Experiences

\begin{tabular}{llll}
\hline & & AIC & AG \\
\hline YEAR LEVEL & Correlation Coefficient & .005 & .008 \\
TYPE RESIDENCE & Pearson Correlation & .032 & .380 \\
MONTHLY FAMILY INCOME & Correlation Coefficient & .000 & .000 \\
MONTHLY BUDGET INTERNET & Correlation Coefficient & .000 & .000 \\
TYPE. INTERNET. CONNECT & Correlation Coefficient & .000 & .000
\end{tabular}

\begin{tabular}{llccc}
\hline SIGNIFICANT RELATIONSHIP BETWEEN PROFILE & & & \\
CHARACTERISTICS AND VIRTUAL LEARNING & & & \\
EXPERIENCES OF THE NURSING STUDENTS & Correlation Coefficient & .287 & .007 & .000 \\
\hline YEAR.LEVEL & Pearson Correlation & .052 & .197 & .124 \\
TYPE.RESIDENCE & Correlation Coefficient & .018 & .007 & .003 \\
MONTHLY.FAMILY. INCOME & Correlation Coefficient & .014 & .004 & .045 \\
MONTHLY.BUDGET. INTERNET & Correlation Coefficient & .000 & .000 & .000 \\
TYPE.INTERNET. CONNECTION & PAR \\
\hline
\end{tabular}
**. CORRELATION IS SIGNIFICANT AT THE 0.01 LEVEL (2-TAILED). 
Based on table 4, the year level was significantly correlated with AIC and AG thus, the null hypothesis has been rejected. This implies that internet connection and gadgets or computers tend to be more available for lower years. In addition, Monthly income was significantly correlated with AIC and AG income thus, the null hypothesis has been rejected and it implies that internet connection and gadgets or computers tend to be more available for high monthly family income. Moreover, the type of internet connection was significantly correlated with AIC and AG thus, the null hypothesis has been rejected. This means that internet access and gadgets or laptops are more readily available for router connection. Smartphones do not provide the desired speed and WiFi sharing quickly drains the mobile battery power, portable routers and WiFi modems are becoming more popular as more convenient and dependable options [5]. Moreover, between the Profile and Virtual Learning Experiences, year level was significantly correlated with ALSR and PADLER thus, the null hypothesis has been rejected, which implies that higher years tend to be more pressured in accomplishing laboratory skills and performing alternative delivery of learning requirements. Meanwhile, on Monthly family income, it was significantly correlated with SAR, ALSR, and PADLER thus, the null hypothesis has been rejected. It implies that respondents with higher monthly family income tend to be less pressured in the submission of academic requirements, accomplishing laboratory skills, and performing alternative delivery of learning requirements. On the other hand, the Monthly budget for the internet was significantly correlated with SAR, ALSR, and PADLER thus, the null hypothesis has been rejected. For the type of Internet connection, it was significantly correlated with SAR, ALSR, and PADLER thus, the null hypothesis has been rejected which implies that respondents with router connection tend to be less pressured in the submission of academic requirements, accomplishing laboratory skills, and performing alternative RLE requirements. Router speed ratings can now exceed 1 Gbps (Bradley Mitchell, 2021.). When it comes to virtual learning, using wireless routers is more convenient.

Table 5. Significant Relationship between Profile Characteristics and Coping Strategies

\begin{tabular}{lll}
\hline YEAR LEVEL & Correlation Coefficient & .007 \\
TYPE RESIDENCE & Pearson Correlation & .533 \\
MONTHLY FAMILY INCOME & Correlation Coefficient & .001 \\
MONTHLY BUDGET INTERNET & Correlation Coefficient & .001 \\
TYPE INTERNET CONNECTION & Correlation Coefficient & .000 \\
\hline
\end{tabular}

**. CORRELATION IS SIGNIFICANT AT THE 0.01 LEVEL (2-TAILED).

Based on table 5, Year level was significantly correlated with coping strategies in virtual learning correlation thus, the null hypothesis has been rejected. This implied that higher years tend to have higher coping strategies. Due to their lack of academic experience, students in their first year of university may exhibit lower levels of self-efficacy than students with more academic experience [1]. Likewise, another study claims that adolescents are more adaptable in terms of coping (E.A. Skinner, $\mathrm{n}$.d.). And lastly, Monthly family income, the monthly budget for the internet, and the type of internet connection were significantly correlated with coping strategies thus, the null hypothesis has been rejected. This implies that the higher the monthly family income, the higher the monthly budget for the internet, and the use of routers as internet connection tend to have lower coping strategies.

\section{CONCLUSION}

In conclusion, most of the respondents are second-year and the majority are from rural areas. Based on the gathered data, most of the respondents belonged to a low-income group (but not poor). It also found that the majority of respondents spent Php 1,001 to Php 1,500 per month on virtual learning. In terms of internet type, the majority used a router connection. Nursing students who were subjected to flexible learning face a variety of technological resources challenges such as unstable internet connection and scarcity of technological resources. All variables were significantly correlated except for the type of residence. These barriers might be a foreseeable risk to compromise learning. To augment with the current situation, students develop coping strategies as their way to keep up to discussions and learning. Facilitating interventions to resolve these barriers can resolve these difficulties.

\section{Acknowledgements}

The researchers would like to express their sincerest gratitude to the following people who willingly and generously contributed to the success of this endeavor. First of all, to the Almighty God, who bestows His blessings all the time and for making this research possible. To our research adviser Cheena B. Mallari $M A N, \boldsymbol{R N}, \boldsymbol{L P T}$, for allowing us to pursue this study, for guiding us, for being the person who always gives answers to our questions without holding back, and never leaves us. To our nursing research 
instructor Zuzette B. Catabona, MAN, $R N$ for her efforts in teaching and reminding us of core research concepts, giving us pieces of advice and valuable lessons towards the proper etiquette and manners. To $D r$. Jean N. Guillasper, $R N$, for her motherly supervision, providing us guidance and support. And to the rest of the panelists who shared their precious time and positive insights. And lastly, To the Respondents, for their time, effort, and honesty, who willingly participated in this study, that gives us the information we needed to finish this study.

\section{REFERENCES}

[1] S. H. Kim and J. Bagaka, "The digital divide in students' usage of technology tools: A multilevel analysis of the role of teacher practices and classroom characteristics," Contemp. Issues Technol. Teach. Educ., vol. 5, no. 3/4, 2005.

[2] S. El Firdoussi, M. Lachgar, H. Kabaili, A. Rochdi, D. Goujdami, and L. El Firdoussi, "Assessing Distance Learning in Higher Education during the COVID-19 Pandemic," Educ. Res. Int., vol. 2020, 2020, doi: 10.1155/2020/8890633.

[3] J. Francis, “The Effects Of Technology On Student Motivation AndThe Effects Of Technology On Student Motivation And Engagement In Classroom-Based LearningEngagement In Classroom-Based Learning," Eff. Technol. Student Motiv. AndThe Eff. Technol. Student Motiv. Engagem. ClassroomBased Learn. Classroom-Based Learn., 2017, [Online]. Available: https://www.google.com/url?sa=t\&rct=j\&q=\&esrc=s\&source=web\&cd=\&cad=rja\&uact=8\&ved=2ah UKEwjiyZykzJT1AhVB_GEKHRkrCocQFnoECAIQAQ\&url=https\%3A\%2F\%2Fdune.une.edu\%2F cgi\%2Fviewcontent.cgi\%3Farticle\%3D1120\%26context\%3Dtheses\&usg=AOvVaw1BNR9btULtUH 7b935Q6nZh.

[4] J. Z. Tria, "The COVID-19 Pandemic through the Lens of Education in the Philippines: The New Normal," Int. J. Pedagog. Dev. Lifelong Learn., vol. 1, no. 1, 2020, doi: 10.30935/ijpdll/8311.

[5] Zyxel, "Bring Your Connection with You: Wi-Fi Goes Mobile," 2021.

[6] Bradley Mitchell, "How to Pick the Right Wireless Router."

[7] M. Z.-G. E.A. Skinner, "Coping Strategies." 